\title{
Bladder Cancer pT4 TNM Finding v6
}

National Cancer Institute

\section{Source}

National Cancer Institute. Bladder Cancer pT 4 TNM Finding v6. NCI Thesaurus. Code C61216.

Bladder cancer with invasion to the prostate, uterus, vagina, pelvic wall or abdominal wall. (from AJCC 6th Ed.) 